\title{
KUALITAS HIDUP PASIEN HIPERTENSI RAWAT JALAN RUMAH SAKIT SWASTA DI YOGYAKARTA YANG MENDAPATKAN TERAPI ANGIOTENSIN RECEPTOR BLOCKERS (ARB) DAN KOMBINASI OBAT LAIN
}

\author{
QUALITY OF LIFE OF HYPERTENSIVE OUTPATIENTS RECEIVING \\ ANGIOTENSIN RECEPTOR BLOCKERS (ARB) THERAPY AND OTHER \\ DRUG COMBINATIONS AT A PRIVATE HOSPITAL IN YOGYAKARTA
}

\author{
Faridah Baroroh*, Willy Nurul Ichwan, Andriana Sari \\ Fakultas Farmasi Universitas Ahmad Dahlan \\ *Penulis Koresponsi, e-mail : faridah@pharm.uad.ac.id
}

\begin{abstract}
ABSTRAK
Kualitas hidup yang buruk pada seseorang dapat diakibatkan karena perasaan tidak nyaman, terapi dengan obat antihipertensi sering berhubungan dengan munculnya efek samping yang tidak nyaman. Tujuan penelitian ini adalah untuk mengetahui apakah ada perbedaan kualitas hidup pasien hipertensi yang diberi terapi angiotensin receptor blockers (ARB) dan kombinasi obat lain. Metode penelitian ini adalah observasional analitik melalui pendekatan cross sectional. Teknik pengambilan sampel purposive sampling, lokasi penelitian di rumah sakit swasta di Yogyakarta. Analisis data dengan skoring kuesioner EQ5D dimensi menjadi EQ5D indeks, dilanjutkan uji Mann-Whitney. Hasil penelitian dari 55 pasien yang memenuhi kriteria inklusi dan eksklusi, kualitas hidup tertinggi dengan nilai indeks EQ5D 0,933 dan kualitas hidup terendah dengan nilai indeks EQ5D 0,243. Kualitas hidup yang sangat bermasalah dari empat dimensi yaitu perawatan diri, kegiatan yang biasa dilakukan, rasa sakit/tidak nyaman, rasa cemas/depresi. Kualitas hidup yang paling banyak mempunyai masalah yaitu pada dimensi rasa kesakitan/tidak nyaman $(50,9 \%)$. Terdapat hubungan signifikan usia $(p=0,008)$ dengan kualitas hidup, dan tidak terdapat hubungan signifikan jenis kelamin $(p=0,857)$, pendidikan $(p=0,079)$, pekerjaan $(p=0,507)$ dengan kualitas hidup. Tidak ada perbedaan signifikan $(p=0,317)$ kualitas hidup pasien hipertensi yang mendapatkan terapi angiotensin receptor blockers (ARB) dan kombinasi obat lain. Kesimpulan penelitian, tidak ada perbedaan signifikan $(p=0,317)$ kualitas hidup pasien hipertensi yang mendapatkan terapi angiotensin receptor blockers (ARB) dan kombinasi obat lain.
\end{abstract}

Kata kunci : kualitas hidup, hipertensi, angiotensin receptor blockers (ARB) 


\section{ABSTRACT}

Quality of life is affected by a feeling of discomfort, a side effect frequently associated with therapies with antihypertensive drugs. This research was intended to identify differences in quality of life between hypertensive patients treated with angiotensin receptor blockers $(A R B)$ and other drug combinations. This research employed an analytical cross-sectional (observational) design and, using the inclusion and exclusion criteria, selected 55 patients at a private hospital in Yogyakarta by purposive sampling. The data were first processed by scoring the EQ5D questionnaire to obtain dimensional EQ5D index, then correlation and Mann-Whitney tests were performed. The results showed that the EQ5D index ranged between 0.243 (lowest) and 0.933 (highest). Quality of life was found to be very problematic in four dimensions, namely self-care, regular activities, pain/discomfort, and anxiety/depression, with pain/discomfort posing the most challenging issue (50.9\%). While age had a significant relationship with quality of life $(p=0.008<0.05)$, sex ( $p=$ $0.857>0.05)$, education $(p=0.079>0.05)$, and occupation $(p=0.507>0.05)$ did not appear to correlate with it. Also, there was no statistically significant difference $(p=0.317)$ in the quality of life of hypertensive patients receiving angiotensin receptor blockers (ARB) therapy and other drug combinations. As a conclusion, ARB and other drug combinations therapies do not affect the quality of life of the patients differently.

Keywords: quality of life, hypertension, angiotensin receptor blockers (ARB)

\section{PENDAHULUAN}

Hipertensi dapat menurunkan kualitas hidup yang terkait dengan kesehatan atau health related quality of life (HRQOL) (Khaw and Latiffah, 2011). Kualitas hidup yang buruk pada seseorang dapat diakibatkan karena perasaan tidak nyaman, terapi dengan obat antihipertensi sering berhubungan dengan munculnya efek samping yang tidak nyaman (Rustiani et al., 2014). Intervensi pada pasien hipertensi yang efektif harus memastikan HRQOL yang diinginkan dan dapat mengontrol tekanan darah untuk mencegah atau mengurangi komorbiditas hipertensi (Khaw and Latiffah, 2011). Pengukuran kualitas hidup merupakan salah satu cara yang dapat membantu tenaga kesehatan dan masyarakat untuk mengetahui gambaran kondisi pasien, sehingga dapat melakukan perawatan penyakit hipertensi dengan baik (Trevisol et al., 2011). Kualitas hidup yang terkait dengan kesehatan atau health related quality of life (HRQOL) meliputi aspek fisik, psikologis, dan sosial dari bidang kesehatan yang dipengaruhi oleh pengalaman pribadi seseorang, kepercayaan, harapan serta persepsi (Donald, 2009). Salah satu alat untuk mengukur kualitas hidup seseorang yaitu metode european quality of life 5 dimension (EQ5D) (Rabin, 2001). EQ5D 
merupakan salah satu metode HRQOL yang paling umum dan sederhana serta mencakup lima dimensi kesehatan yaitu mobilitas, perawatan diri, aktivitas yang biasa dilakukan, nyeri/ketidaknyamanan, dan kecemasan/depresi (Foundation, 2018). Dimana salah satu metode yang dapat digunakan untuk mengukur kualitas hidup pasien hipertensi adalah metode EQ5D (Sari and Baroroh, 2017). Responden dapat menunjukkan kesehatan mereka di masing-masing dimensi pada tiga tingkatan ordinal: tidak ada masalah, beberapa atau sedang masalah, dan masalah berat atau ekstrim (Foundation, 2018).

Hubungan antara penyakit hipertensi dengan kualitas hidup yang rendah, diperkirakan akibat dari pengaruh komplikasi hipertensi (Soni et al., 2010). Terapi dengan obat antihipertensi sering berhubungan dengan munculnya efek samping yang tidak nyaman, yang berakibat pada kualitas hidup seseorang (Rustiani et al., 2014).

Antihipertensi paling banyak digunakan pada pengobatan pasien hipertensi rawat jalan adalah kombinasi 2 antihipertensi, golongan $\mathrm{CCB}+\mathrm{ARB}$ yaitu amlodipin+candesartan dan herbesser $\mathrm{CD}+$ candesartan, masing-masing 9 pasien $(12,33 \%)$ (Baroroh and Fathonah, 2017). Terapi kombinasi CCB dan ARB lebih efektif dari pada monoterapi dalam mengurangi tekanan darah, hal ini disebabkan karena kejadian edema perifer yang terjadi akibat penggunaan obat golongan CCB bisa diatasi oleh ARB melalui efek vasodilatasi vena dan arterial secara bersamaan. Kombinasi ini tepat untuk mengurangi kematian kardiovaskular, infark miokard, dan stroke (Gradman et al., 2010). Kombinasi olmesartan (ARB) dan azelnidipine (CCB) memiliki keunggulan dibandingkan kombinasi olmesartan (ARB) dan tiazid (diuretik) dalam hal menghindari hiperurisemia, aktivasi simpatis, stimulasi sistem renin-angiotensin-aldosteron, inflamasi, stres oksidatif, dan peningkatan kekakuan arteri pada hipertensi (Ishimitsu et al., 2009). Tujuan dari penelitian ini adalah untuk mengetahui apakah ada perbedaan kualitas hidup pasien hipertensi yang diberi terapi tunggal angiotensin receptor blockers (ARB) dengan terapi kombinasi ARB dan CCB dan golongan diuretik. 


\section{METODE PENELITIAN}

Penelitian ini dilaksanakan atas persetujuan Komite Etik (Ethical Approval) Universitas Ahmad Dahlan dengan nomer 011802024. Semua pasien yang terlibat dalam penelitian ini telah menandatangani formulir informed consent dan penelitian dilakukan sesuai dengan pedoman Praktik Klinik yang Baik. Penelitian ini merupakan penelitian kuantitatif dengan jenis penelitian observasional analitik melalui pendekatan cross sectional, pengumpulan data dilakukan dengan pengisian kuesioner EQ5D3L yang telah divalidasi. Subyek penelitian adalah pasien hipertensi rawat jalan rumah sakit swasta di Yogyakarta. Subyek penelitian adalah pasien hipertensi dengan atau tanpa komplikasi yang telah melakukan pengobatan secara rutin 3 bulan sebelumnya dan yang mendapatkan terapi tunggal antihipertensi golongan ARB dengan terapi kombinasi golongan ARB dengan obat lain yaitu golongan CCB dan golongan diuretik. Teknik sampling yang digunakan dalam penelitian ini adalah purposive sampling.

Penentuan nilai kualitas hidup dengan melakukan skoring kuesioner EQ5D dilanjutkan konversi EQ5D dimensi menjadi EQ5D Indeks, skoring kuesioner EQ5D dilakukan dengan melihat nilai indeks ringkasan tunggal pada tiap dimensi. Analisis data untuk menganalisis hubungan jenis kelamin, usia, pendidikan, dan pekerjaan dengan kualitas hidup menggunakan uji korelasi Spearman dan uji korelasi koefisien kontingensi. Analisis perbedaan kualitas hidup berdasarkan terapi ARB dan kombinasi obat lain menggunakan uji Mann-Whitney.

\section{HASIL DAN PEMBAHASAN}

Subyek penelitian yang sesuai dengan kriteria inklusi dan eksklusi sebanyak 55 pasien. Antihepertensi yang digunakan pada 18 pasien dalam penelitian ini adalah golongan ARB (irbesartan, valsartan, dan candesartan), 25 pasien pengobatan kombinasi ARB dengan golongan CCB (amplodipin, nifedipine, dan diltiazem), dan 12 pasien pengobatan kombinasi ARB dengan golongan diuretik (furosemid dan spironolakton). Subyek penelitian mayoritas perempuan $63,6 \%$, dengan usia $>60$ tahun sebesar $61,8 \%$. Tingkat pendidikan terbanyak adalah lulusan SMA sebesar 42\%, pasien tidak bekerja sebesar 61,8\%. Hasil pengukuran kualitas hidup tertinggi dengan nilai indeks EQ5D 0,933 
$(29,1 \%)$ dan kualitas hidup terendah dengan nilai indeks EQ5D 0,243(1,8\%). Kualitas hidup tertinggi memiliki nilai EQ5D indeks sebesar 0,933, nilai tertinggi berdasarkan EQ5D value set Malaysia. Nilai indeks EQ5D 0,933 (29,1\%) mempunyai kualitas hidup yang baik karena tidak mempunyai masalah di setiap dimensi seperti berjalan/bergerak, perawatan diri, kegiatan yang biasa dilakukan, rasa kesakitan/tidak nyaman, dan rasa cemas/depresi. Hal ini sejalan dengan penelitian (Sari and Baroroh, 2017) sebanyak 22,4\% yang memiliki nilai indeks 1,00 yang berarti mempunyai nilai kualitas hidup yang baik. Pasien yang mempunyai kualitas hidup yang baik artinya mereka mampu menjaga diri dengan baik dari berbagai faktor yang dapat mempengaruhi/memperburuk kualitas hidup. Kualitas hidup pasien hipertensi hasil skoring kuesioner EQ5D yang telah dikonversi ke EQ5D dimensi disajikan pada Tabel I.

Tabel I. Kualitas hidup pasien hipertensi berdasarkan dimensi EQ5D

\begin{tabular}{lccc}
\hline \multicolumn{1}{c}{ Dimensi EQ5D } & $\begin{array}{c}\text { Nilai 1 } \\
\text { (Tidak } \\
\text { ada } \\
\text { masalah) }\end{array}$ & $\begin{array}{c}\text { Nilai 2 } \\
\text { (Ada } \\
\text { masalah) }\end{array}$ & $\begin{array}{c}\text { Nilai 3 } \\
\text { (Sangat } \\
\text { ada } \\
\text { masalah) }\end{array}$ \\
\hline & $\mathrm{n}(\%)$ & $\mathrm{n}(\%)$ & $\mathrm{n}(\%)$ \\
Berjalan/bergerak & $36(65,5)$ & $19(34,5)$ & - \\
Perawatan diri & $50(90,9)$ & $3(5,5)$ & $2(3,6)$ \\
Kegitan yang biasa dilakukan & $42(76,4)$ & $9(16,4)$ & $4(7,2)$ \\
Rasa kesakitan/ tidak nyaman & $27(49,1)$ & $26(47,3)$ & $2(3,6)$ \\
Rasa cemas/ depresi & $35(63,6)$ & $19(34,6)$ & $1(1,8)$ \\
\hline
\end{tabular}

Berdasarkan Tabel I terdapat masalah pada kelima dimensi yang paling banyak mempunyai masalah yaitu pada dimensi rasa kesakitan/tidak nyaman sebesar 50,9\% yang didapat dari poin nilai 2 (ada masalah) dan nilai 3 (sangat ada masalah). Hal ini sejalan dengan penelitian (Baroroh and Sari, 2019) dimana pasien merasa bermasalah dengan persentase terbesar pada dimensi rasa kesakitan/ tidak nyaman. Pada dimensi rasa kesakitan/tidak nyaman sebesar 5,36\% merasa sangat bermasalah, 51,79\% bermasalah dan 
42,86\% tidak bermasalah. Hal ini sejalan dengan penelitian (Sari et al., 2017) hasil penelitiannya menyatakan bahwa pasien yang paling sedikit mempunyai masalah yaitu pada domain perawatan diri sebesar 9,1\% karena mayoritas pasien masih bisa melakukan perawatan diri sendiri seperti mandi dan berpakain sendiri.

Hasil analisis hubungan antara karakteristik pasien (jenis kelamin, usia, pekerjaan, dan pendidikan) dengan kualitas hidup pasien hipertensi rawat jalan dapat dilihat pada Tabel II.

Tabel II. Analisis hubungan karakteristik pasien dengan kualitas hidup

\begin{tabular}{llccc}
\hline Karakteristik & & $\mathbf{n}(\%)$ & $\begin{array}{c}\text { Koefisien } \\
\text { Korelasi }\end{array}$ & p-value \\
\hline Jenis kelamin & Perempuan & $35(63,6)$ & 0,024 & 0,857 \\
& Laki-laki & $20(36,4)$ & & \\
Usia & $<60$ & $21(38,2$ & 0,335 & 0,008 \\
& $>60$ & $34(61,8)$ & & \\
Pendidikan & Rendah & $12(21,8)$ & & \\
& Sedang & $4(7,3)$ & 0,239 & 0,079 \\
& Tinggi & $39(70,9)$ & & \\
Pekerjaan & Bekerja & $21(38,2)$ & 0,091 & 0,507 \\
& Tidak Bekerja & $34(61,8)$ & & \\
\hline
\end{tabular}

Berdasarkan hasil analisis korelasi pada tabel II, tidak terdapat hubungan yang signifikan $(p=0,857)$ antara jenis kelamin dengan kualitas hidup pasien hipertensi. Hal ini menunjukkan bahwa peluang terjadinya kualitas hidup baik ataupun buruk pada laki-laki dan perempuan pasien hipertensi adalah sama. Hasil penelitian ini sejalan dengan penelitian (Baroroh and Sari, 2019) tidak ada hubungan signifikan ( $>00,350)$ antara jenis kelamin dengan kualitas hidup pasien.

Terdapat hubungan yang signifikan $(p=0,008)$ antara usia dengan kualitas hidup pasien hipertensi. Dengan demikian pasien hipertensi semakin bertambah usianya maka 
kualitas hidupnya semakin buruk. Begitu juga pada hasil penelitian (Kularatna et al., 2014) menunjukkan bahwa usia, pendidikan dan status pekerjaan berpengaruh secara signifikan pada kualitas hidup seseorang setelah monopause.

Hasil analisa tingkat pendidikan menunjukkan bahwa tidak terdapat hubungan yang signifikan $(p=0,079)$ antara pendidikan dengan kualitas hidup pasien hipertensi. Seseorang dengan tingkat pendidikan yang lebih tinggi seharusnya memiliki kualitas hidup lebih baik dibandingkan seseorang dengan tingkat pendidikan rendah. Hasil penelitian juga berbeda dengan (Sinuraya et al., 2018) juga menyatakan bahwa seseorang dengan pendidikan yang tinggi mempunyai faktor literasi yang semakin baik, dimana ia akan mudah mengakses berbagai informasi mengenai kesehatan sehingga tetap dapat menjaga kesehatan dan memperbaiki kualitas hidupnya.

Tidak terdapat hubungan yang signifikan $(p=0,507)$ antara status pekerjaan dengan kualitas hidup pasien hipertensi, sehingga dapat dikatakan bahwa pasien yang bekerja ataupun yang tidak bekerja tidak ada hubungan sama sekali terkait dengan kualitas hidupnya. Seharusnya terdapat hubungan yang signifikan dimana seseorang yang bekerja mempunyai penghasilan sehingga dapat digunakan untuk melakukan pengobatan terhadap penyakitnya dan seseorang yang bekerja biasanya aktif dalam melakukan aktivitas gerak tubuh setiap hari artinya hal tersebut dapat mencegah seseorang tersebut untuk terkena penyakit seperti hipertensi. Hasil tersebut sejalan dengan penelitian (Kaitelidou et al., 2011) yang menyatakan bahwa seseorang yang melakukan pekerjaan dapat banyak melakukan aktivitas fisik dan dapat menurunkan tekanan darah dibandingkan seseorang yang tidak bekerja karena mempunyai keterbatasan aktivitas fisik.

Antihipertensi yang digunakan pada pasien dalam penelitian ini adalah golongan ARB (irbesartan, valsartan, dan candesartan), golongan CCB (amplodipin, nifedipine, dam diltiazem), dan golongan diuretik (furosemid dan spironolakton). Pada penelitian juga dilakukan uji beda, untuk mengetahui apakah ada perbedaan kualitas hidup berdasarkan jenis terapi tunggal antihipertensi golongan ARB dengan terapi kombinasi golongan ARB dengan obat lain yaitu golongan $\mathrm{CCB}$ dan golongan diuretik. Uji beda yang digunakan 
adalah Mann Whitney, hasil uji beda kualitas hidup pasien hipertensi rawat jalan dapat dilihat pada Tabel III.

Tabel III. Perbedaan kualitas hidup pasien hipertensi berdasarkan terapi

\begin{tabular}{ccc}
\hline Jenis terapi & $\boldsymbol{N}$ & $\boldsymbol{p}$-value \\
\hline ARB & 18 & \multirow{2}{*}{0,317} \\
ARB-kombinasi & 37 & \\
\hline
\end{tabular}

Berdasarkan uji beda pada Tabel III menunjukkan bahwa tidak ada perbedaan yang signifikan $(p=0,317)$ kualitas hidup pasien hipertensi yang mendapatkan terapi tunggal antihipertensi golongan ARB dengan terapi kombinasi golongan ARB dengan obat lain yaitu golongan $\mathrm{CCB}$ dan golongan diuretik. Hasil penelitian ini sejalan dengan penelitian (Baroroh et al., 2020) yang menyatakan bahwa tidak ada perbedaan yang signifikan ( $>0,05)$ kualitas hidup pasien hipertensi yang mendapatkan terapi candesartan dengan candesartan-amplodipin. Hasil penelitian (Shanableh et al., 2014) juga mengatakan tidak ada perbedaan yang signifikan antara penggunaan terapi tunggal inhibitor pengubah angiotensin (ACEI) atau penghambat reseptor angiotensin (ARB) dan menggunakan terapi kombinasi terapi kombinsai ARB-Diuretik, diketahui hampir sama memiliki skor pada sebagian besar dimensi menggunakan SF 36. (Rustiani et al., 2014) melalui uji statistik penggunaan jenis obat hipertensi, menunjukkan bahwa tidak ada perbedaan bermakna untuk kualitas hidup antara pasien yang mendapatkan terapi tunggal ataupun kombinasi.

\section{KESIMPULAN}

Tidak ada perbedaan yang bermakna ( $p=0,317)$ kualitas hidup pasien hipertensi yang mendapatkan terapi tunggal angiotensin receptor blockers (ARB) dengan terapi kombinasi ARB-CCB dan ARB-golongan diuretik.

\section{DAFTAR PUSTAKA}

Baroroh, F., \& Fathonah, S. S. (2017). Biaya medik langsung terapi hipertensi pasien rawat 
Jalan di Rumah Sakit X Yogyakarta. Jurnal Farmasi Sains Dan Praktis, 3(2), 6-13

Baroroh, F., \& Sari, A. (2019). Correlation between the Characteristics and quality of life of hypertensive outpatients at a private Hospital in Yogyakarta, Ahmad Dahlan International Conference Series on Pharmacy and Health Science. Ahmad Dahlan International Conference Series on Pharmacy and Health Science, 18, 144-146

Baroroh, F., Sari, A., \& Hanifah, R. (2020). Quality of life of hypertensive patients with candesartan and candesartan-amlodipine combination therapy at a governmental hospital in Yogyakarta, Indonesia. Journal of Global Pharma Technology, 12(9), 242246

Donald, A. (2009). What is quality of life? Second Edition, Health Economics. Hayward Medical Communications, 1(9), 1-6

Foundation, E. R. (2018). Research EQ-5D-3L User Guide. https://euroqol.org/publications/user-guides/

Gradman, A. H., Basile, J. N., Carter, B. L., \& Bakris, G. L. (2010). Combination therapy in hypertension. Journal of the American Society of Hypertension, 4(1), 42-50

Ishimitsu, T., Numabe, A., Okamura, T. M. T. A. A., Minami, J., \& Matsuoka, H. (2009). Angiotensin-II receptor antagonist combined with calcium channel blocker or diuretic for essential hypertension. Japanese Society of Hypertension, 32(11), 962-968

Kaitelidou, M. T. D., Galanis, P., Middleton, N., Stafylas, P. T. P., Siskou, O., \& Maniadakis, N. (2011). Quality of life measurement in patients with hypertension in Cyprus. Hellenic Journal of Cardiology, 52, 407-415

Kularatna, S., Whitty, J. A., Johnson, N. W., Jayasinghe, R., \& Scuffham, P. A. (2014). Derived population norms for health-related quality of life in Sri Lanka. PLoS One, 
$9(11), 1-12$

Rustiani, E., Andrajati, R., \& Arsyanti, L. (2014). Analisis penggunaan obat Hipertensi di poliklinik rawat jalan rumah Sakit PMI Bogor: perbandingan cost effectiveness dan kualitas hidup pasien. Jurnal Ilmu Kefarmasian Indonesia, 12(2), 209-215

Sari, A., \& Baroroh, F. (2017). Kualitas hidup pasien hipertensi rawat jalan di Rumah Sakit PKU Muhammadiyah Bantul Yogyakarta dengan terapi kombinasi angiotensin reseptor blocker dan calcium channel blocker. Jurnal Sains dan Teknologi Farmasi, 19(1), 8-10

Sari, A., Lolita, \& Fauzia. (2017). Pengukuran kualitas Hidup Pasien Hipertensi di Puskesmas Mergangsang Yogyakarta menggunakan European Quality Of Life 5 Dimensions (EQ5D) Questionnaire dan Visual Analog Scale (VAS). Jurnal Ilmiah Ibnu Sina, 2(1), 1-12

Shanableh, S., Abdulkarem, M. S. A., \& Sarhan, F. (2014). Quality Of life of hypertensive patients on different types of antihypertensive medications. IOSR Journal Of Pharmacy, 4(5), 23-28

Sinuraya, R. K., Destiani, D. P., Puspitasari, I. M., \& Diantini, A. (2018). Tingkat kepatuhan pengobatan pasien hipertensi di fasilitas kesehatan tingkat pertama di kota Bandung. Journal Farmasi Kinik Indonesia, 7(2), 124-133

Soni, R. K., Porter, A. C., Lash, J. P., \& Unruh, M. L. (2010). Health-related quality of life in hypertension, chronic kidney disease and coexistent chronic health conditions. Advances in Chronic Kidney Disease, 17(4), 17-26

Trevisol, D. J., Moreira, L. B., Kerkhoff, A., Fuchs, S. C., \& Fuchs, F. D. (2011). Health related quality of life anf hypertention: a systematic review and meta-analysis of 
observational studies. Journal of Hypertensio, 29(2), 88-178

W.F. Khaw, S. T. S. H., \& Latiffah, A. L. (2011). Health-related Quality of Life among Hypertensive Patients Compared with General Population Norms. Journal of Medical Sciences, 11(2), 84-89 